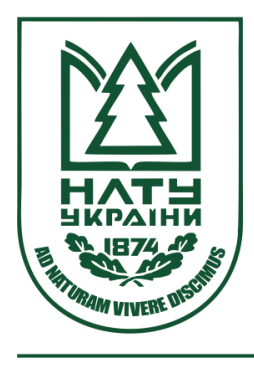

Науковий вісник НЛтУ України Scientific Bulletin of UNFU

https://nv.nltu.edu.ua

https://doi.org/10.36930/40310406

$@ \bowtie$ Correspondence author

Article received 28.05.2021 p.

Article accepted 09.09.2021 p.

S. B. Kovalevskii

UDC 502/504:630*232:622.339(477.42)

s.kovalevsky@ukr.net

С. Б. Ковалевський, Ю. М. Марчук, К. В. Маєвський, С. С. Ковалевський, А. М. Чурілов

Національний університет біоресурсів і природокористування України, м. Київ, Украӥна

\title{
КОМПЛЕКСНИЙ ПІДХІД ДО РЕАБІЛІТАЦІЇ ЛІСОВИХ ЗЕМЕЛЬ ЖИТОМИРСЬКОГО ПОЛІССЯ, ПОШКОДЖЕНИХ НЕПРОМИСЛОВИМ ВИДОБУТКОМ БУРШТИНУ
}

3'ясовано, що питання комплексного підходу до відновлення лісових земель, порушених внаслідок несанкціонованого видобутку бурштину непромисловими методами на території Житомирського Полісся, є відносно новим і потребує подальшого вивчення. Відсутність аналогів у світовій практиці рекультивації пов'язана, передусім, із специфічним характером ушкоджень лісових земель під час видобутку непромисловими методами. У контексті роботи вивчено та класифіковано основні типи пошкоджень вкритих лісовою рослинністю територій, що утворилися внаслідок видобутку бурштину. Встановлено, що одним $з$ негативних наслідків, який істотно ускладнює відновлення пошкоджених ділянок, $є$ значне підвищення кислотності субстратів. Розроблено комплексний спосіб відновлення порушених лісових ділянок з урахуванням їх кислотності, який охоплює стимулювання процесів природного заростання, видалення сухостійних дерев, ліквідацію захаращеності, часткове зняття попередньо нанесеного на грунти шару розкривних порід та засипання ям, планування поверхні грунту та низку агротехнічних заходів. Так, зокрема, в разі виявлення середнього значення $\mathrm{pH}$ верхнього шару субстрату ділянки в межах 5,5-7,0 - залишають її під природне поновлення, проводячи догляд за лісовими насадженнями, що існували на ній до пошкодження з урахуванням сучасного стану грунту. Якщо $\mathrm{pH}$ становить $3,5-5,5$, додатково вносять мінеральні добрива, готують грунт під посадку ацидофільних культур, створюють лісові культури за прийнятими в лісовому господарстві технологіями та схемами змішування відповідно до типів лісорослинних умов та типів лісу. Якщо показник $\mathrm{pH}<3,5$, додатково проводять вапнування закислених грунтів, вносять доломітовий вапняк, проводять оранку та висівають навесні однорічні сидеральні культури трав'яних рослин, виконують повторну оранку наступної весни, вносять мінеральні добрива, створюють лісові культури з переважанням швидкорослих деревних видів, здатних ефективно депонувати вуглець. Окрім цього, за важкого ступеня ушкодження ділянок у контексті реабілітації територій, запропоновано облаштування пожежних водойм відповідних параметрів, використовуючи при цьому вийнятий, під час створення чаші грунт для відсипання під'ізних шляхів та ремонту грунтових лісових доріг.

Ключові слова: рекультивація; дендрорекультивація; бурштин; грунт; кислотність; пожежні водойми.

\section{Вступ / Introduction}

Україна має значні природні ресурси, зокрема корисні копалини. Рівень розвитку країни залежить від можливості їх видобутку, наявності сучасних прогресивних технологій та охорони природи. Серед видобутку корисних копалин на особливу увагу заслуговує питання розроблення родовищ бурштину на територіях Українського Полісся [13, 14, 15].

Особливо нагально ця проблема постала останніми роками через пошкодження земель лісогосподарського призначення внаслідок несанкціонованого видобутку бурштину непромисловими методами в низці областей Українського Полісся.

У багатьох країнах світу на законодавчому рівні врегульовано питання видобутку корисних копалин та компенсації завданих збитків. У світовій практиці існуе низка технологій поетапного процесу відведення територій під видобуток корисних копалин, зокрема й бурштину, використання інших природних ресурсів, що розташовані на цій території, самого процесу видобутку мінералів та відновлення пошкоджених територій із заподіянням мінімальної шкоди довкіллю.

Інформація про авторів:

Ковалевський Сергій Борисович, д-р с.-г. наук, професор, кафедра ботаніки, дендрології та лісової селекції. Email: s.kovalevsky@ukr.net; https://orcid.org/0000-0002-0506-6055

Марчук Юрій Миколайович, канд. с.-г. наук, доцент, кафедра ботаніки, дендрології та лісової селекції. Email: dendrology.nudip@gmail.com

Маєвський Костянтин Васильович, канд. с.-г. наук, доцент, кафедра ботаніки, дендрології та лісової селекції. Email: kv_maevsky@nubip.edu.ua

Ковалевський Сергій Сергійович, канд. с.-г. наук, доцент, кафедра ботаніки, дендрології та лісової селекції. Email: kovalevskyis.s@nubip.edu.ua

Чурілов Андрій Михайлович, канд. біол. наук, доцент, кафедра ботаніки, дендрології та лісової селекції. Email: churilov_konf@ukr.net; https://orcid.org/0000-0003-4153-9136

Цитування за Дсту: Ковалевський С. Б., Марчук Ю. М., Маєвський К. В., Ковалевський С. С., Чурілов А. М. Комплексний підхід до реабілітації лісових земель Житомирського Полісся, пошкоджених непромисловим видобутком бурштину. Науковий вісник НЛтУ України. 2021, т. 31, № 4. С. 43-47.

Citation APA: Kovalevskii, S. B., Marchuk, Yu. M., Maevskii, K. V., Kovalevskyi, S. S., \& Churilov, A. M. (2021). A comprehensive approach to the rehabilitation of forest lands of Zhytomyr Polissya damaged by non-industrial amber production. Scientific Bulletin of UNFU, 31(4), 43-47. https://doi.org/10.36930/40310406 
На сьогодні немає чітко встановленого порядку рекультивації земель, що зазнали антропогенного перетворення внаслідок несанкціонованого видобутку бурштину-сирцю, також відсутня законодавча база щодо врегулювання цієї проблеми.

Об'єкт дослідження - землі Житомирського ОУЛМГ, що були вкриті лісовою рослинністю та постраждали внаслідок несанкціонованого видобутку бурштину непромисловими методами.

Предмет дослідження - основні типи ушкоджень лісових земель, що виникли внаслідок несанкціонованого видобутку бурштину, та шляхи їх відновлення.

Мета роботи - розроблення комплексного підходу для реабілітації лісових земель Житомирщини, що були порушені внаслідок несанкціонованого видобутку бурштину.

Для досягнення зазначеної мети визначено такі основні завдання дослідження:

1. Проаналізувати типи ушкоджень лісових земель, що виникають під час видобутку бурштину непромисловими методами та визначити основні з них.

2. Розглянути сучасні підходи до рекультивації та відновлення подібних земель.

3. Розробити власний комплексний підхід для реабілітації порушених лісових земель з урахуванням ступеня їх ушкодження та особливостей природних умов Житомирщини.

Наукова новизна отриманих результатів дослідження - проаналізовано основні наслідки несанкціонованого видобутку бурштину на лісових землях Житомирщини; визначено тип пошкоджених земель - умовний показник, що дає змогу комплексно описати характер поверхні, грунт; розроблено комплексний підхід для їх реабілітації.

Практична значущість результатів дослідження розроблено ефективний та легкий у здійсненні спосіб рекультивації лісових земель, порушених під час непромислового добування бурштину.

Аналіз останніх досліджень та публікацій. Питання комплексного підходу до відновлення лісових земель, порушених унаслідок несанкціонованого видобутку бурштину непромисловими методами на території Українського Полісся, зокрема Житомирської області, є відносно новим і потребує детального вивчення. Наукові публікації з цієї проблематики присвячені супутниковому моніторингу порушених територій [4], оцінюванню екологічних наслідків і економічних збитків $[8,9]$, заподіяних несанкціонованим видобутком бурштину. У класичних фундаментальних роботах $з$ лісової рекультивації та фітомеліорації [7, 10, 12] також немає даних про шляхи відновлення земель після подібних специфічних ушкоджень. Так, згідно з ДСТУ 7941: 2015 "Якість грунту" [2]. Рекультивація земель. Загальні вимоги", рекультивацію земель потрібно здійснювати відповідно до виду порушень (відкриті гірські роботи, підземні, добування торфу тощо). Проте непромислове добування бурштину є змішаним типом порушень, i, відповідно до вимог ДСТУ 7941:2015 [2], недостатньо опрацьоване, щоб ефективно здійснювати рекультивацію на державному рівні в усіх порушених територіях України. Застосування земель, порушених унаслідок добування бурштину для сільськогосподарського, лісогосподарського, водогосподарського, санітарного та рекреаційного напрямів неможливе або обмежене, ос- кільки дієвого способу рекультивації таких земель на сьогодні фактично немає. Відсутність аналогів у світовій практиці рекультивації пов'язана насамперед із специфічним характером ушкоджень лісових земель [6].

Масовий видобуток бурштину непромисловими методами на території Житомирської області розпочався дещо пізніше, ніж у сусідніх регіонах. Це стало однією 3 передумов того, що загальна площа пошкоджених територій, є меншою, ніж зокрема в сусідній Рівненській області [5].

Матеріали та методи дослідження. Дослідження проводили впродовж 2017-2020 рр. на території земель лісового фонду Житомирської області. Також здійснили низку виїздів на території Рівненської та Волинської областей, щоб порівняти типи ушкоджень та їх масштаби.

На території Житомирського ОУЛМГ дослідження безпосередньо здійснювали на територіях ДП "Білокоровицьке ЛГ" $(20,21,22$ та 25 квартали Поясківського лісництв $a)$, ДП "Олевське ЛГ" (60 та 64 квартали Юрівського лісництв $a$ ). Тимчасові пробні площі закладали у місцях найінтенсивнішого видобутку бурштину, що мали характерні ушкодження.

Вихідними матеріалами для роботи $є$ результати польових досліджень, таксаційні описи насаджень, супутникові та аерофотознімки, дані спеціалізованої літератури, накази та розпорядження державних органів влади України. Дослідження проводили відповідно до загальноприйнятих у лісовому господарстві методик [3]. Технологію створення лісових культур, здійснення господарських заходів у них відновили за архівними даними і матеріалами лісовпорядкування, а також уточнили під час обстеження в натурі, з урахуванням особливостей стану територій на момент дослідження [5].

Для визначення фізико-хімічних властивостей грунту закладали шурфи завглибшки 1,2-1,5 м до материнської породи і відбирали зразки для аналізу. Агрохімічний аналіз зразків субстратів і листову діагностику виконано стандартними методами відповідно у лабораторіях родючості і охорони грунтів кафедри грунтознавства та охорони грунтів ім. проф. М. К. Шикули та фізіології рослин кафедра фізіології, біохімії рослин та біоенергетики НУБіП України [1].

Обробляння вихідного матеріалу виконували з допомогою програмних засобів Turboveg for Windows 2.127b, статистичне оброблення матеріалу проводили у середовищі MS Excel 2016, Statistica 8.0, STATGRAFICS - 3.0.

\section{Результати дослідження та їх обговорення / Research results and their discussion}

Дані лісовпорядкування та візуальне обстеження порушених ділянок вказують на те, що внаслідок незаконного видобутку бурштину були знищені переважно середньовікові насадження Pinus sylvestris L., місцями 3 домішкою Quercus robur L., також молодняки Betula pendula Roth. та пристигаючі насадження Alnus glutinosa (L.) Gaertn. Здебільшого лісостани були суцільно вирубані, а іноді випалені разом з піднаметовим вкриттям. Частина насаджень, зокрема молодняки Betula pendula Roth. загинула після залиття верхнього шару грунту пульпою із піщаних горизонтів унаслідок гідронамиву мотопомпами. На багатьох ділянках намивні роботи призвели до порушення рівня грунтових вод.

За результатами обстеження ділянок встановлено низку типів порушень грунтового покриву. Це, зокрема, 
канали для підводу води до гідропомп, декілька типів кратерів, ями від первинного та вторинного ручного копання та так звані ями-шахти з укріпленими стінками. За результатами аналізу лісівничо-таксаційних показників насаджень на пошкоджених ділянках встановлено, що найбільшу кількість пошкоджених площ мають ТЛУ та ТЛ В3-дС, В3-дсО та В2-дС. Найбільше пошкоджено насаджень 3 переважанням сосни звичайної, а за віковою структурою - деревостани віком 60-80 років. Частина досліджуваних порушених земель (див. табл. 1) унаслідок намивів має низькі значення водневого показника.

Табл. 1. Кислотність грунтів на тимчасових пробних площах (ТIII) / Soil acidity for temporary sample plots (TSP)

\begin{tabular}{|c|c|c|c|c|}
\hline $\begin{array}{l}\text { № } \\
\text { ТПП }\end{array}$ & $\begin{array}{l}\text { № кварта- } \\
\text { лу та ви- } \\
\text { ділу }\end{array}$ & $\begin{array}{c}\text { № } \\
\text { проби }\end{array}$ & $\begin{array}{c}\text { pH проби } \\
\text { грунту }\end{array}$ & $\begin{array}{c}\text { Безпосереднє місце відбо- } \\
\text { ру проби грунту в межах } \\
\text { ТПП }\end{array}$ \\
\hline \multicolumn{5}{|c|}{ ДП "Білокоровицьке ЛГ", Поясківське лісництво } \\
\hline 1 & $\begin{array}{l}\text { кв. } 21 \text {, } \\
\text { вид. } 5\end{array}$ & $\begin{array}{l}1 \\
2 \\
3\end{array}$ & $\begin{array}{l}5,0^{ \pm 0,1} \\
3,5^{ \pm 0,1} \\
4,0^{ \pm 0,1}\end{array}$ & $\begin{array}{c}\text { поверхня грунту, } \\
\text { вкрита шаром пульпи } \\
\text { близько } 10 \text { см, } \\
\text { дно лунки кратеру }\end{array}$ \\
\hline 2 & $\begin{array}{l}\text { кв. 21, } \\
\text { вид. } 7\end{array}$ & $\begin{array}{l}1 \\
2 \\
3\end{array}$ & $\begin{array}{l}5,5^{ \pm 0,1} \\
3,5^{ \pm 0,1} \\
3,5^{ \pm 0,1}\end{array}$ & $\begin{array}{l}\text { поверхня грунту, вкрита } \\
\text { шаром пульпи близько } \\
10 \text { см, дно лунки кратеру }\end{array}$ \\
\hline 3 & $\begin{array}{l}\text { кв. 21, } \\
\text { вид. }\end{array}$ & $\begin{array}{l}1 \\
2 \\
3\end{array}$ & $\begin{array}{l}6,5^{ \pm 0,1} \\
5,6^{ \pm 0,1} \\
6,0^{ \pm 0,1}\end{array}$ & $\begin{array}{c}\text { поверхня грунту, } \\
\text { дно ями (глибина } 225 \text { см) } \\
\text { край відвалу грунту } 3 \text { ями }\end{array}$ \\
\hline 4 & $\begin{array}{l}\text { кв. } 21 \text {, } \\
\text { вид. } 18\end{array}$ & $\begin{array}{l}1 \\
2 \\
3\end{array}$ & $\begin{array}{l}5,5^{ \pm 0,1} \\
4,1^{ \pm 0,1} \\
3,5^{ \pm 0,1}\end{array}$ & $\begin{array}{l}\text { поверхня грунту, } \\
\text { дно лунки кратеру, } \\
\text { край лунки кратеру }\end{array}$ \\
\hline 5 & $\begin{array}{l}\text { кв. 20, } \\
\text { вид. } 17\end{array}$ & $\begin{array}{l}1 \\
2 \\
3\end{array}$ & $\begin{array}{l}4,0^{ \pm 0,1} \\
3,0^{ \pm 0,1} \\
3,5^{ \pm 0,1}\end{array}$ & $\begin{array}{l}\text { поверхня грунту, } \\
\text { дно лунки кратеру, } \\
\text { край лунки кратеру }\end{array}$ \\
\hline 6 & $\begin{array}{l}\text { кв. 20, } \\
\text { вид. } 20\end{array}$ & $\begin{array}{l}1 \\
2 \\
3\end{array}$ & $\begin{array}{l}7,1^{ \pm 0,1} \\
4,0^{ \pm 0,1} \\
6,1^{ \pm 0,1}\end{array}$ & $\begin{array}{l}\text { поверхня грунту, } \\
\text { дно лунки кратеру, } \\
\text { край лунки кратеру }\end{array}$ \\
\hline 7 & $\begin{array}{l}\text { кв. } 20 \text {, } \\
\text { вид. } 32\end{array}$ & $\begin{array}{l}1 \\
2 \\
3\end{array}$ & $\begin{array}{l}7,1^{ \pm 0,1} \\
4,0^{ \pm 0,1} \\
6,1^{ \pm 0,1}\end{array}$ & $\begin{array}{l}\text { поверхня грунту, } \\
\text { дно лунки кратеру, } \\
\text { край лунки кратеру }\end{array}$ \\
\hline 8 & $\begin{array}{l}\text { кв. } 22, \\
\text { вид. } 26\end{array}$ & $\begin{array}{l}1 \\
2 \\
3\end{array}$ & $\begin{array}{l}4,1^{ \pm 0,1} \\
4,0^{ \pm 0,1} \\
5,1^{ \pm 0,1}\end{array}$ & $\begin{array}{l}\text { поверхня грунту, } \\
\text { поверхня грунту, } \\
\text { поверхня грунту }\end{array}$ \\
\hline 9 & $\begin{array}{l}\text { кв. 22, } \\
\text { вид. } 28\end{array}$ & $\begin{array}{l}1 \\
2 \\
3\end{array}$ & $\begin{array}{l}6,1^{ \pm 0,1} \\
6,0^{ \pm 0,1} \\
6,5^{ \pm 0,1}\end{array}$ & $\begin{array}{l}\text { поверхня грунту, } \\
\text { поверхня грунту, } \\
\text { поверхня грунту }\end{array}$ \\
\hline 10 & $\begin{array}{l}\text { кв. } 20 \text {, } \\
\text { вид. } 32\end{array}$ & $\begin{array}{l}1 \\
2 \\
3\end{array}$ & $\begin{array}{l}7,0^{ \pm 0,1} \\
4,5^{ \pm 0,1} \\
5,5^{ \pm 0,1}\end{array}$ & $\begin{array}{c}\text { поверхня грунту, } \\
\text { дно лунки кратеру, } \\
\text { край лунки кратеру }\end{array}$ \\
\hline 11 & $\begin{array}{l}\text { кв. } 22 \text {, } \\
\text { вид. } 27\end{array}$ & $\begin{array}{l}1 \\
2 \\
3\end{array}$ & $\begin{array}{l}5,6^{ \pm 0,1} \\
6,0^{ \pm 0,1} \\
6,5^{ \pm 0,1}\end{array}$ & $\begin{array}{l}\text { поверхня грунту, } \\
\text { поверхня грунту, } \\
\text { поверхня грунту }\end{array}$ \\
\hline \multicolumn{5}{|c|}{ ДП "Олевське ЛГ", Юрівське лісництво } \\
\hline 12 & $\begin{array}{l}\text { кв. } 65 \text {, } \\
\text { вид. } 14\end{array}$ & $\begin{array}{l}1 \\
2 \\
3\end{array}$ & $\begin{array}{l}6,5^{ \pm 0,1} \\
3,0^{ \pm 0,1} \\
5,5^{ \pm 0,1}\end{array}$ & $\begin{array}{c}\text { поверхня грунту, } \\
\text { дно ями (глибина } 255 \text { см, } \\
\text { стоїть вода), } \\
\text { край відвалу грунту з ями }\end{array}$ \\
\hline 13 & $\begin{array}{l}\text { кв. } 60 \text {, } \\
\text { вид. } 25\end{array}$ & $\begin{array}{l}1 \\
2 \\
3 \\
\end{array}$ & $\begin{array}{l}6,0^{ \pm 0,1} \\
3,0^{ \pm 0,1} \\
5,5^{ \pm 0,1}\end{array}$ & $\begin{array}{c}\text { поверхня грунту } \\
\text { дно лунки кратеру } \\
\text { край лунки кратеру }\end{array}$ \\
\hline 14 & $\begin{array}{l}\text { кв. } 60 \text {, } \\
\text { вид. } 37\end{array}$ & $\begin{array}{l}1 \\
2 \\
3\end{array}$ & $\begin{array}{l}6,5^{ \pm 0,1} \\
3,0^{ \pm 0,1} \\
5,8^{ \pm 0,1}\end{array}$ & $\begin{array}{c}\text { поверхня грунту вкрита } \\
\text { шаром пульпи } \\
\text { дно лунки кратеру } \\
\text { край лунки кратеру }\end{array}$ \\
\hline
\end{tabular}

Подальше застосування кислих грунтів земель, де добували бурштин, для заліснення природним шляхом - неможливе, оскільки, за результатами досліджень авторів, виявлено ділянки $3 \mathrm{pH}=2,5$. За останні 3-5 років на таких територіях так і не з'явилися жодні види вищих рослин. Кислотність грунту призводить до елементної токсичності для рослин солей алюмінію, заліза, марганцю і цинку через підвищену розчинність цих елементів за низьких значень рН. Кислотність грунту може спричинити обмежену доступність деяких макроі мікроелементів, таких як фосфор, котрий зв'язується 3 оксидами заліза і алюмінію в кислих грунтах. Інші елементи в доступних для рослин формах, такі як молібдати різного складу, проявляють знижену розчинність за низьких значень $\mathrm{pH}$. Мікробна активність знижується в кислих умовах, які можуть знизити концентрації азоту (основної поживної речовини для рослин), зменшуючи фіксацію азоту і мінералізацію азоту, два процеси, життєво важливі для створення доступних рослинам форм азоту. Розкладання органічних речовин грунтовими організмами сповільнюється, розвивається дефіцит кальцію, магнію і калію. Тут варто зазначити, що усунення підвищеної кислотності грунтів не передбачене при традиційному підході до рекультивації згідно 3 ДСТУ 7941:2015.

Нашим завданням було розробити ефективний та легкий у здійсненні спосіб рекультивації лісових земель, порушених під час непромислового добування бурштину 3 урахуванням типу здійснення видобутку, виду грунтів, порушень грунту, властивостей намивів, наявності осередків рослинності минулих насаджень лісу та масштабів порушення.

Завдання вирішують тим, що першочергово визначають тип пошкоджень залежно від вихідних даних ділянок (табл. 2), на яких виявлені порушення земель. Тип пошкоджених земель - умовний показник, що дає змогу комплексно описати характер поверхні, грунт. Для типів 1, 2, 3, 4 за мінімального ступеня пошкодження допустимо залишати ділянки під природне поновлення. За решти типів пошкоджень потрібне термінове здійснення рекультивації, що може тривати декілька років залежно від ступеня пошкоджень.

Табл. 2. Класифікація типів пошкоджень земель внаслідок непромислового добування бурштину / Classification of land damage types after amber industrial mining

\begin{tabular}{|c|c|c|c|c|c|}
\hline $\begin{array}{c}\text { Спосіб } \\
\text { видобут- } \\
\text { ку бур- } \\
\text { штину }\end{array}$ & $\begin{array}{c}\text { Вид } \\
\text { заглиблення }\end{array}$ & $\begin{array}{c}\mathrm{pH} \mathrm{y} \\
\text { заглиб- } \\
\text { ленні }\end{array}$ & $\begin{array}{c}\mathrm{pH} \\
\text { грунту } \\
\text { намиву }\end{array}$ & $\begin{array}{c}\text { Вид } \\
\text { намиву }\end{array}$ & $\begin{array}{c}\text { Тип пош- } \\
\text { коджених } \\
\text { земель }\end{array}$ \\
\hline \multirow{3}{*}{ Ручний } & cyxe & \multirow{2}{*}{$H$} & \multirow{2}{*}{$H$} & $M$ & 1 \\
\hline & \multirow{2}{*}{ вологе } & & & $C$ & 2 \\
\hline & & $\bar{K}$ & $H$ & $M$ & 3 \\
\hline \multirow{14}{*}{$\begin{array}{l}\text { Гідроме- } \\
\text { ханічний }\end{array} \mid$} & \multirow{4}{*}{$\begin{array}{c}\text { Лунка (глиби- } \\
\text { на 0,15-0,5 м; } \\
\text { діаметр } \\
1,0-1,5 \text { м) }\end{array}$} & \multirow{2}{*}{$K$} & \multirow{2}{*}{$K$} & $M$ & 4 \\
\hline & & & & $C$ & 5 \\
\hline & & \multirow{2}{*}{$H$} & \multirow{2}{*}{$H$} & $M$ & 6 \\
\hline & & & & $C$ & 7 \\
\hline & \multirow{4}{*}{$\begin{array}{c}\text { Ями глибокі } \\
\text { (глибина } \\
2,0-2,5 \text { м) }\end{array}$} & \multirow{2}{*}{$K$} & \multirow{2}{*}{$K$} & $M$ & 8 \\
\hline & & & & $C$ & 9 \\
\hline & & \multirow{2}{*}{$H$} & \multirow{2}{*}{$H$} & $M$ & 10 \\
\hline & & & & $C$ & 11 \\
\hline & \multirow{4}{*}{$\begin{array}{l}\text { "Колодязі" } \\
\text { (глибина } \\
\text { до } 10 \text { м) }\end{array}$} & \multirow{2}{*}{$K$} & \multirow{2}{*}{$K$} & $M$ & 12 \\
\hline & & & & $C$ & 13 \\
\hline & & \multirow{2}{*}{$H$} & \multirow{2}{*}{$H$} & $M$ & 14 \\
\hline & & & & $C$ & 15 \\
\hline & \multirow{2}{*}{$\begin{array}{c}\text { Канали підве- } \\
\text { дення води }\end{array}$} & $K$ & $K$ & $M$ & 16 \\
\hline & & $H$ & $H$ & $M$ & 17 \\
\hline
\end{tabular}

Примітка: $K$ - кислий, $H$ - нейтральний водневий показник; $M$ - мозаїчний, $C$ - суцільний вид намиву.

Для кожної ділянки певного типу оцінюють ступінь пошкоджень (табл. 3). Дендрорекультивацію здійснюють так. Шар піску чи розкривних порід знімають так, щоб до грунту залишився шар завтовшки 10-15 см, після чого визначають $\mathrm{pH}$ залишеного шару, видаляють сухостій дерев, ліквідують захаращеність на ділянках, 
розрівнюють грунт, засипають заглиблення, знімаючи шар розкривних порід, механічно скошують трав'яні рослини, видаляють самосів небажаних деревних видів, за $\mathrm{pH}$ грунтів намивів в межах 5,5-7,0 залишають ділянку під природне поновлення, проводять догляд за насадженнями, що існували на ділянці до її пошкодження.

Табл. 3. Рівні ступенів пошкодження земель внаслідок добування бурштину / Levels of land damage degrees due to amber mining

\begin{tabular}{|c|c|c|c|c|c|}
\hline $\begin{array}{c}\text { Ступінь пошкодження } \\
\text { земель видобутку }\end{array}$ & $\begin{array}{c}\text { Густина ділянок за } \\
\text { мозаїчних нами- } \\
\text { вів, од./га }\end{array}$ & $\begin{array}{c}\text { Площа суцільних } \\
\text { ділянок намивів, } \\
\text { га/га }\end{array}$ & $\begin{array}{c}\text { Відстань діля- } \\
\text { нок до стіни лі- } \\
\text { су, м } \\
\end{array}$ & $\begin{array}{c}\text { Наявність живих на- } \\
\text { саджень } 3 \text { минулих } \\
\text { посадок лісу, од./га }\end{array}$ & $\begin{array}{c}\text { Варіант здійснення } \\
\text { способу рекультива- } \\
\text { ції }\end{array}$ \\
\hline Мінімальний & $1-10$ & $0-0,2$ & $<100$ & $>8000$ & 1 \\
\hline Середній & $10-50$ & $0,2-0,5$ & $100-150$ & $5000-8000$ & 2 \\
\hline Важкий & $\geq 50$ & $0,5-1$ & $>150$ & $<5000$ & 3 \\
\hline
\end{tabular}

Якщо рН пошкоджених грунтів знаходиться в межах 3,5-5,5, то додатково вносять мінеральні добрива, готують грунт під посадку ацидофільних рослин, створюють лісові культури за прийнятими в лісовому господарстві технологіями та схемами змішування, відповідно до типів лісорослинних умов та типів лісу.

Якщо для грунтів намивів $\mathrm{pH}<3,5$, то додатково проводять вапнування закислених грунтів, вносять доломітовий вапняк, орють та висівають навесні однорічні сидеральні культури трав'яних рослин, виконують повторну оранку наступної весни, вносять мінеральні добрива, створюють лісові культури 3 переважанням швидкорослих видів, здатних ефективно депонувати вуглець. За важкого ступеня ураження ділянок викопують чаші пожежних водойм, використовують вийнятий грунт для відсипання під'їзних шляхів та ремонту грунтових лісових доріг. Такі водойми створюються на об'єктах промислового виробництва і в населених пунктах, які не обладнані централізованою системою водозабезпечення. Під час влаштування протипожежної водойми, окрім загально будівельних моментів, необхідно враховувати вимоги нормативних документів 3 пожежної безпеки, що стосуються протипожежних водойм, зокрема: ДБН В.2.5-74:2013 [11], "Правил пожежної безпеки в Україні", "Правил пожежної безпеки в лісах України", "Положення про лісові пожежні станції", затверджених наказами відповідних міністерств та відомств України.

Під час створення водойми необхідно влаштувати під'їзні майданчики з твердим покриттям і розмірами не менш ніж $12 \times 12$ м для вільного проїзду і розташування пожежних автомобілів у будь-яку пору року, або приймальні колодязі, які також мають бути забезпечені вільним проїздом і можливістю для розташування техніки.

До основних етапів влаштовування пожежної водойми відносять:

- розрахункові роботи мінімального об'єму води та водойми загалом;

- виконання пошукових робіт з підбору місця розташування водойми;

- визначення географічної форми водойми, 3 урахуванням формування безпечних берегів;

- розроблення проекту;

- виконання технологічних робіт з підготовки котловану;

- створення гідроізоляції;

- облаштування під'їзних доріг, за потреби - насосної станції.

Для розрахунку об'єму пожежних водойм і резервуарів потрібно враховувати розрахунок витрати води та тривалість гасіння пожежі за формулою: "Тривалість гасіння (у секундах)×Витрата води (л/с)". Випаровування води в літній період і утворення криги взимку потрібно теж враховувати під час виконання розрахунків загального об'єму води у водоймі. Верхній край дамби повинен бути вищим не менше як на 0,5 м над рівнем води.
До підготовчих робіт відносять: проведення геодезичного дослідження з подальшою розміткою території; зняття верхнього шару грунту; під час розрахунків і будівництва дамби потрібно врахувати можливість появи хвиль, які можуть спричинити їх руйнування з подальшою ерозією грунтів. Також необхідно передбачити будівництво дренажної системи, яка дасть змогу регулювати рівень води у водоймі під час дощу, або в разі близького залягання грунтових вод. У процесі викопування котловану його стінки потрібно ущільнити та закріпити.

Під час будівництва протипожежних водойм, для формування гідроізоляційного шару можна використовувати глину, яка запобігає розмиванню та зсуву грунту. Наразі у будівництві водних споруд часто застосовують гідроізоляційні плівки і мембрани. Однак у місцях 3 підвищеним рівнем грунтових вод, до яких належать досліджувані ділянки Житомирської області, можливе облаштування пожежних водойм без спеціальної мембрани, за умови, що в літній період не відбувається зменшення об'єму на $50 \%$ і більше, та відповідно не знижується рівень води, що унеможливлює використання пожежної авіації.

Спеціальні приймальні колодязі об'ємом 3-5 м³ створюють за умови, якщо безпосередній забір з пожежної водойми автонасосами і мотопомпами ускладнений. При цьому необхідно розрахувати діаметр трубопроводу, що буде з'єднувати водойму з колодязем, з урахуванням пропускання розрахункової витрати води. Для лісових пожежних водойм також дуже важливою $є$ можливість забору води засобами пожежної авіації. Тому запроектована водойма повинна мати відповідні параметри глибини (не менше 3 м) та форму і площу водної поверхні (не менше 0,5 га).

Постійний високий рівень грунтових вод упродовж усього сезону в таких районах, зокрема Поясківському лісництві ДП "Білокоровицьке ЛГ", дає змогу не використовувати геомембрану під час облаштування пожежної водойми. Втілення у життя запропонованих методів і способів відтворення лісових ділянок, ушкоджених унаслідок несанкціонованого видобутку бурштину та проведення дендрорекультивації, сприятиме повному відтворенню знищених лісових насаджень.

\section{Висновки / Conclusions}

Визначено та проаналізовано основні типи характерних порушень вкритих лісовою рослинністю територій Житомирського Полісся внаслідок несанкціонованого видобутку бурштину непромисловими методам.

Розроблено комплексний спосіб дендрорекультивації порушених лісових ділянок з урахуванням кислотності. Він містить стимулювання процесів природного заростання, видалення сухостійних дерев, ліквідацію захаращеності, часткове зняття попередньо нанесеного 
на грунти шару розкривних порід та засипання ним, планування поверхні грунту, скошування трав'яних рослини та видалення самосіву небажаних деревних видів, причому за:

- $\mathrm{pH}=5,5-7,0$ - залишають ділянку під природне поновлення, проводять догляд за лісовими насадженнями, що існували на ділянці до іiі пошкодження з урахуванням сучасного стану грунту;

- $\mathrm{pH}=3,5-5,5$ - додатково вносять мінеральні добрива, готують грунт під посадку ацидофільних культур, створюють лісові культури за прийнятими в лісовому господарстві технологіями та схемами змішування відповідно до типів лісорослинних умов та типів лісу;

- $\mathrm{pH}<3,5$ додатково проводять вапнування закислених грунтів, вносять доломітовий вапняк, орють та висівають навесні однорічні сидеральні культури трав'яних рослин, виконують повторну оранку наступної весни, вносять мінеральні добрива, створюють лісові культури з переважанням швидкорослих видів, здатних ефективно депонувати вуглець.

Також за важкого ступеня ураження ділянок викопують чаші пожежних водойм відповідних параметрів, використовуючи вийнятий грунт для відсипання під'їзних шляхів та ремонту грунтових лісових доріг.

\section{References}

1. Arinushkina, E. V. (1970). Rukovodstvo po himicheskomu analizu pochvy. Moscow: MGU, 239 p. [In Russian].

2. Brovko, F., et al. (2016). DSTU 7941:2015. Iakist gruntu. Rekultyvatsiia zemel. Zahalni vymohy. Kyiv: DP "UkrNDNTs", 8 p. [In Ukrainian].

3. Gordienko, M., Mayrer, V., \& Kovalevskiy, S. (2000). Methodological guidelines for the study and research of forest crops. Kyiv: NAUU publishing, $103 \mathrm{p}$. [In Ukrainian].

4. Kazimir, M., \& Bedernichek, T. (2017). Reclamation of lands disturbed as a result of amber mining in Polissya: problems and prospects. Economics of nature management: state, problems, prospects, 1, 90-94. [In Ukrainian].
5. Kovalevskii, S., Marchuk, Y., Maevskii, K., Kurduk, A., \& Kovalevskii, S. (2018). The condition of the plantations of Zhytomyr $\mathrm{RDFH}$ for the areas damaged as a result of amber mining. Scientific works of the Forestry Academy of Sciences of Ukraine, 17, 133-140. [In Ukrainian].

6. Kovalevsky, S., \& Kovalevskyi, S. (2019). Amber minerals: history of study, extraction methods and impact on forest ecosystems. Scientific Bulletin of NLTU of Ukraine, 29(3), 56-60. https://doi.org/10.15421/40290312

7. Kucheriavyi, V., Henyk, Ia., Dyda, A., \& Kolodko, M. (2006). Reclamation and phyto-melioration. Lviv, 116 p. [In Ukrainian].

8. Nadtochii, P. (2015). Ecological-economic assessment of the impact of activities related to the illegal mining of amber on the state of the environment of Zhytomyr region. Bulletin of the Zhytomyr National Agroecological University, 1(47), 28-50. [In Ukrainian].

9. Nadtochii, P., \& Myslyva, T. (2015). Environmental consequences of amber mining in Zhytomyr region. Zhytomyr National Agroecological University, 50 p. [In Ukrainian].

10. Nadtochii, P., Myslyva, T., \& Morozov, V. (2007). Protection and rational use of natural resources and land reclamation. Zhytomyr: Zhytomyr National Agroecological University, 420 p. [In Ukrainian].

11. Ohloblia, O., et al. (2013). Vodopostachannia. Zovnishni merezhi ta sporudy. Osnovni polozhennia proektuvannia: DBN V.2.574:2013. Kyiv: Ministerstvo rehionalnoho rozvytku, budivnytstva ta zhytlovo-komunalnoho hospodarstva Ukrainy, 281 p. [In Ukrainian].

12. Pylypenko, O., Yukhnovskyi, V., Dudarets, S., \& Maliuha, V. (2010). Forest melioration. Kyiv: Ahrarna osvita, 282 p. [In Ukrainian].

13. Trembitskyi, V., Myslyva, T., Marteniuk, O., \& Biliavskyi, Iu. (2011). Atlas of agro-ecological status of soil cover of Zhytomyr region. Zhytomyr: PPTs "Oblderzhrodyuchist", 56 p. [In Ukrainian].

14. Vasylyshyn, I., Panchenko, V., \& Maydanovych, I. (1995). Amber of Ukraine. Mineral resources of Ukraine, 3-4, 28-32. [In Ukrainan]

15. Vyshnivskyi, O., \& Kushnir, S. (2007). Amber of Ukraine. Notes of the Ukrainian Mineralogical Society, 4, 128-130. [In Ukrainian].

S. B. Kovalevskii, Yu. M. Marchuk, K. V. Maevskii, S. S. Kovalevskyi, A. M. Churilov

National University of Life and Environmental Sciences of Ukraine, Kyiv, Ukraine

\section{A COMPREHENSIVE APPROACH TO THE REHABILITATION OF FOREST LANDS OF ZHYTOMYR POLISSYA DAMAGED BY NON-INDUSTRIAL AMBER PRODUCTION}

Over the past decade, the issue of overcoming the destructive consequences for the nature by the illegal mining of amber has become especially urgent for Ukraine. The literature sources on the issue of this paper were analyzed. Therefore, the topic is found to be relevant and require further studying. A classification of the main types of damage to forest lands of Zhytomyr region as a result of amber mining is presented. The conditional levels of damage to forest areas have been determined. In the course of research the damage to the environment and its consequences are revealed to be quite specific. One of these consequences is a significant increase in soil acidity. All these factors complicate the use of analogues known in the literature for the rehabilitation of such lands. Based on the research results, a comprehensive method for restoring disturbed forest areas taking into account their acidity was developed. This method provides stimulating the processes of natural overgrowing of disturbed forest areas, cutting down dead trees, eliminating litter, partial removal of the bottom layer previously applied to the soil and filling holes, levelling the soil surface, and a number of agrotechnical measures as well. In particular, with a $\mathrm{pH}$ value of the upper layer of the substrate areas in the range of 5.5-7.0, they leave it under natural overgrowth, conducting forest plantations care that existed there before damage, with the current state of the soil. When the $\mathrm{pH}$ is 3.5-5.5, mineral fertilizers are additionally introduced; the soil is prepared for planting acidophilic crops, forest cultures are created according to the technologies and mixing schemes adopted in forestry in accordance with the types of forest conditions and forest types. Providing the $\mathrm{pH}$ is $<3.5$, the soils are additionally deoxidized by liming, plowing is carried out and one-yearold green manure crops of grass plants are sown in the spring, and repeated plowing is performed. The following spring, mineral fertilizers are applied to the site, and forest crops are created with a predominance of fast-growing tree species capable of efficiently depositing carbon. On the other hands, where the plot is very badly damaged and has a high level of groundwater occurrence on the territory, in such a way it is proposed to build fire reservoirs. The soil removed from the pit will be used to create access roads to the reservoir and repair dirt forest roads. Applying the integrated approach to the rehabilitation of forest lands will enable more effective overcoming the negative consequences of amber mining by non-industrial methods and at the same time solve a number of other problems. In particular, to increase the fire safety of the regions forests, improve communication routes and create new recreation areas.

Keywords: reclamation; dendrorecultivation; amber; soil; acidity; fire reservoirs. 